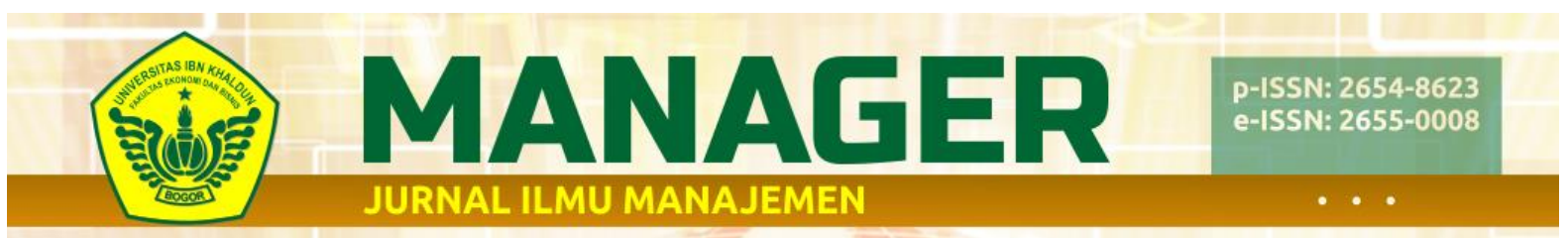

Vol. 3, No. 2, Mei 2020, Hal. 237-245 @) (1) http://ejournal.uikabogor.ac.id/index.php/Manager/index

\title{
ANALISIS RASIO UNTUK MENGUKUR RASIO INDUSTRI PADA PERUSAHAAN MANUFAKTUR SUB SEKTOR PROPERTI
}

\author{
Elida Triana, Titing Suharti, Diah Yudhawati \\ Fakultas Ekonomi dan Bisnis, Universitas Ibnu Khaldun Bogor, Indonesia \\ elida.triana@yahoo.com, titing@gmail.com, diahyudhawati@gmail.com
}

\begin{abstract}
This study aims to determine the industry ratio average of manufacturing companies in the property sub sector listed on the Indonesia Stock Exchange in 2013 - 2018. The research is descriptive, where the data analyzed in the form of secondary data. Sampling in this study uses purposive sampling in manufacturing companies in the property sub sector, with issuers PT Agung Podomoro land Tbk, PT Alam Sutera Realty Tbk, PT Bekasi Fajar Industrial Estate Tbk, PT Bhuawanatala Tbk, PT Bumi Citra Permai Tbk, PT Bumi Serpong Damai Tbk, PT Lippo Cikarang Tbk, PT Lippo Karawaci Tbk, PT Sentul City Tbk. From the research results obtained by industry averages from 2013 to 2018 for the Current ratio: $187.45 \%, 172.27 \%, 267.47 \%, 265.42 \%, 246.87 \%$, 306.89\%. The average industry ratio Debt to Asset ratio: $45.41 \%, 43.89 \%, 46.54 \%, 44.32 \%, 43.93 \%, 43.38 \%$. The average industry ratio Debt to Equity ratio: $0.95 \%, 0.79 \%, 0.98 \%, 0.93 \%, 0.85 \%, 0.83 \%$. The average ratio of Retrun on equty Profitability ratios: $18.06 \%, 11.77 \%, 7.96 \%, 8.92 \%, 8.75 \%, 8.32 \%$. The average industry ratio from the Net Profit Margin Profitability ratio: $56.82 \%, 31.41 \%$, $32.06 \%, 27.29 \%, 25.04 \%, 21.95 \%$.
\end{abstract}

Keywords: Industry Average

\begin{abstract}
Abstrak
Penelitian ini bertujuan untuk menentukan rata-rata rasio industri pada perusahaan manufaktur sub sektor properti yang terdaftar di Bursa Efek Indonesia tahun 2013 - 2018. Penelitian bersifat deskriptif, dimana data yang dianalisis berupa data sekunder. Penarikan sampel pada penelitian ini menggunakan purposive sampling pada perusahaan manufaktur sub sektor property, dengan emiten PT Agung Podomoro land Tbk, PT Alam Sutera Realty Tbk, PT Bekasi Fajar Industrial Estate Tbk, PT Bhuawanatala Tbk, PT Bumi Citra Permai Tbk, PT Bumi Serpong Damai Tbk, PT Lippo Cikarang Tbk, PT Lippo Karawaci Tbk, PT Sentul City Tbk. Dari hasil penelitian diperoleh rata-rata industri dari tahun 2013- 2018 untuk rasio Current rasio : 187,45\%, 172,27\%, 267,47\%, 265,42\%, 246,87\%, 306,89\%. Rata-rata rasio industri rasio Debt to Asset : 45,41\%, 43,89\%, 46,54\%, 44,32\%, 43,93\%, 43,38\%. Rata-rata rasio industri rasio Debt to Equity : 0,95\%, 0,79\%, 0,98\%, 0,93\%, 0,85\%, 0,83\%. Rata-rata rasio rasio Profitabilitas Return on equty : 18,06\%, 11,77\%, 7,96\%, 8,92\%, 8,75\%, 8,32\%. Rata-rata rasio industri dari rasio Profitabilitas Nett Profit Margin : 56,82\%, 31,41\%, $32,06 \%, 27,29 \%, 25,04 \%, 21,95 \%$.

Kata kunci : Rata Rata Industri
\end{abstract}




\section{Pendahuluan}

Dunia bisnis saat ini sangat maju dengan pesat, sehingga banyak perusahaan baru yang bermunculan disekitar kita. Banyak pengusaha yang mendirikan usaha yang sama dengan pengusaha lain karena melihat peluang yang menguntungkan dari jenis usaha tersebut. Dengan kemunculan jenis usaha yang sama tersebut menimbulkan persaingan diantara mereka. Keberadaan masing-masing perusahaan menjadi ancaman dan menimbulkan persaingan bisnis yang biasa terjadi karena banyak perusahaan yang berjenis sama.

Suatu perusahaan yang bergerak dalam suatu lingkungan bisnis, saat ini tidak dapat melepaskan diri dari persaingan, karena tanpa diduga para pesaing meningkatkan persaingan dipasar dengan berbagai macam cara. Hal ini yang membuat banyak perusahaan melakukan banyak langkah untuk meningkatkan kinerja perusahaan agar tidak kalah bersaing dengan perusahaan lain.

Dengan ketatnya persaingan, perusahaan harus memperbaiki kinerjanya dengan cara meningkatkan efisiensi dan produktivitas usaha. Salah satu cara yang ditempuh untuk memperkuat efisiensi dan produktivitas adalah dengan memperkuat struktur modal perusahaan yaitu dengan jalan menjual sekuritas ke pasar modal. Keputusan perusahaan menjual sekuritas kepasar modal disebut go public. Selain struktur modal perusahaan yang kuat, kinerja perusahaan dapat dilihat dari kemampuan perusahaan dalam melaksanakan kegiatan operasionalnya secara efektif dan efisien dengan didukung oleh manajerial yang baik (Suryaningtyas,2006: 1).

Pada umumnya perusahaan adalah merupakan organisasi yang mencari keuntungan, maka tujuan perusahaan biasanya dinyatakan dalam bentuk uang. Dalam hal ini terdapat dua tujuan utama yang dikemukakan yaitu maksimisasi keuntungan ( profit) dan maksimisasi kemakmuran (Gitosudarmo dan Basri,2002:5). Hal tersebut penting karena kinerja perusahaan secara terus-menerus akan dipantau oleh pihak-pihak yang berkepentingan dengan hal tersebut.

Semua pihak yang berkepentingan dengan perkembangan suatu perusahaan sangatlah perlu untuk mengetahui kondisi keuangan perusahaan tersebut, dan kondisi keuangan suatu perusahaan akan dapat diketahui dari laporan keuangan perusahaan yang bersangkutan (Munawir,2004:1). Menurut Fraser dan Ormiston (dalam Setyautama,2004:1) laporan keuangan membentuk dasar untuk memahami posisi keuangan suatu perusahaan dan menilai kinerja yang telah lampau dan prospek kinerja keuangan perusahaan dimasa yang akan datang. Laporan keuangan memiliki kemampuan untuk menyajikan secara nyata kesehatan keuangan dari perusahaan guna memberikan keputusan bisnis yang informatif.

Laporan keuangan dapat dijadikan alat komunikasi antara data keuangan atau aktivitas perusahaan dengan pihak pihak yang berkepentingan dengan data atau aktivitas perusahaan tersebut. Pihak-pihak yang berkepentingan terhadap posisi keuangan maupun perkembangan suatu perusahaan adalah : para pemilik perusahaan, manajer perusahaan yang bersangkutan, para kreditur, bankers, para investor dan pemerintah dimana perusahaan tersebut berdomisili, buruh serta pihak-pihak lainnya lagi (Munawir,2004:2).

Laporan keuangan akan menjadi lebih bermanfaat untuk digunakan dalam 
pengambilan keputusan ekonomi, apabila informasi keuangan tersebut dapat memprediksikan apa yang akan terjadi dimasa mendatang. Dengan mengolah laporan keuangan menggunakan metode tertentu bisa memprediksi kemungkinan yang akan terjadi dimasa akan datang, disinilah arti penting dari analisis terhadap laporan keuangan.

Banyak alat dan teknik yang digunakan oleh analis laporan keuangan untuk mengubah data keuangan menjadi format yang memudahkan evaluasi kondisi keuangan dan kinerja perusahaan dari waktu kewaktu dan perbandingan dengan kompetitor dalam industri. Hal ini mengikuti ukuran standar laporan keuangan yang menyajikan perkiraanperkiraan neraca sebagai persentase terhadap aktivanya dan setiap perkiraan dalam laba rugi sebagai persentase dari total penjualannya. Rasio-rasio keuangan dapat menstandarkan data keuangan dan melakukan perbandingan industri yang membandingkan satu perusahaan dengan perusahaan lain dengan rata-rata industri dimana perusahaan itu dapat bergerak.

Dalam penelitian ini penulis memilih untuk menggunakan analisis rasio dalam melakukan analisis laporan keuangan yang diteliti oleh penulis. Rasio menggambarkan suatu hubungan atau perimbangan ( mathematical relationship) antara suatu jumlah tertentu dengan jumlah yang lain, dengan menggunakan alat analisa berupa rasio ini dapat menjelaskan atau memberi gambaran kepada penganalisa tentang baik atau buruknya keadaan atau posisi keuangan suatu perusahaan (Munawir,2004:64).

Untuk bidang yang akan diteliti penulis memilih untuk melakukan analisa laporan keuangan pada perusahaanperusahaan yang bergerak dibidang properti. Seperti kita ketahui saat ini banyak sekali masyarakat yang membutuhkan properti yang sesuai dengan kebutuhan masing-masing individu, maka banyak perusahaan properti yang menawarkan berbagai macam produk properti yang sesuai dengan kebutuhan masyarakat tersebut. Saat ini sudah banyak perusahaan yang bergerak dibidang property yang terdaftar di Bursa Efek Indonesia, oleh karena itu peneliti tertarik untuk menulis judul skripsi dengan judul “ Analisis Rasio untuk Mengukur Rasio Industri pada Perusahaan Manufaktur Sub Sektor Properti yang terdapat di Bursa Efek Iindonesia ( Periode 2013 -2018 )."

\section{Metode Penelitian}

Metode yang digunakan dalam penelitian ini adalah metode deskriptif. Metode ini menjelaskan karateristik suatu variable tertentu secara terstruktur dan spesifik (Firdaus, 2012:16). Dimana data yang dianalisis berupa data kuantitatif atau hasil observasi tertentu yang relative cukup banyak. Metode deskriptif adalah suatu metode yang digunakan untuk mengumpulkan, mengklasifikasikan, menganalisa serta menginterprestasikan data yang berhubungan dengan masalah dan membandingkan dengan keadaan yang sebenarnya pada perusahaan kemudian mengambil kesimpulan.

Populasi penelitian adalah perusahaan manufaktur sub sektor properti yang terdaftar di Bursa Efek Indonesia. Penulis memilih sembilan perusahaan dengan menggunakan $\mathrm{p}$. rpasive sampling dengan kriteria perusahaan tersebut konsisten terdaftar di Bursa Effek Indonesia dan memiliki laporan keuangan selama enam tahun yaitu selama periode 2013 - 2018. Perusahaan tersebut adalah : PT Agung Podomoro Land Tbk, PT Alam Sutera Realty Tbk, PT Bekasi Fajar 
Industrial Estate Tbk, PT Bhuawanatala Indah Permai Tbk, PT Bumi Citra Permai Tbk, PT Bumi Serpong Damai Tbk, PT Lippo Cikarang Tbk, PT Lippo Karawaci Tbk, PT Sentul City Tbk. Jenis data-data yang digunakan adalah data kuantitatif, informasi yang berupa symbol angka dan bilangan. Berdasarkan angka tersebut perhitungan secara kuantitatif dapat dilakukan dengan menghasilkan suatu kesimpulan yang berlaku umum didalam suatu parameter. Sumber data yang digunakan dalam penelitian adalah data sekunder yaitu data yang diperoleh dalam bentuk yang sudah jadi berupa publikasi (Firdaus,2012:28). Sumber data penelitian ini diambil dari Laporan Keuangan Perusahaan manufaktur sub sector properti yang terdaftar di Bursa Efek Indonesia periode 2013 - 2018. Analisis data merupakan proses penyederhanaan data kedalam bentuk yang lebih mudah dibaca dan diinterprestasikan. Metode analisis data yang digunakan dalam penelitian ini berupa metode analisa deskriptif, yaitu menggambarkan bagaimana rasio rata rata industri pada perusahaan properti di bursa efek Indonesia dengan menggunakan angka rasio keuangan yaitu rasio industri. Untuk menentukan rata-rata rasio industri maka perlu dilakukan analisis laporan keuangan yang menggunakan rasio-rasio keuangan . Dalam melakukan analisis laporan keuangan, peneliti akan menggunakan beberapa rasio, yaitu : Rasio Likuiditas (current rasio), Rasio Sovabilitas (rasio debt to asset,rasio debt to equity), Rasio Profitabilitas ( rasio return on equity, rasio net profit margin). Pada Umumnya digunakan dua cara untuk menginterprestasikan rasio-rasio keuangan. Dengan menggunakan asumsi bahwa metode yang digunakan oleh perusahaan sama dan konsisten dari waktu kewaktu dengan perusahaan- perusahaan lainnya,maka rasio-rasio keuangan bisa diinterprestasikan dengan cara membandingkan dengan rasio-rasio keuangan perusahaan dimasa lalu.dan membandingkan dengan rasio-rasio keuangan perusahaan lain yang satu industri. Penelitian dilaksanakan pada Juli 2019,dengan objek penelitian yang diperoleh di Bursa Effek Indonesia (BEI), Menara 2 Lantai 1 Jl.Jend Sudirman kav.52-53 Jakarta Pusat 12190 Indonesia. 


\section{Hasil dan Pembahasan}

\section{A. Temuan Penelitian}

Tabel.1

Hasil Analisis rata-rata rasio industri current ratio pada perusahaan manufactur sub sector

properti tahun $2013-2018$ ( dalam \% )

\begin{tabular}{llcccccc}
\hline No & Perusahaan & 2013 & 2014 & 2015 & 2016 & 2017 & 2018 \\
\hline 1. & PT Agung Podomoro Land Tbk & 167,93 & 183,23 & 138,92 & 265,42 & 130,65 & 105,59 \\
\hline 2. & PT Alam Sutra Realty Tbk & 113,73 & 75,29 & 71,92 & 148,16 & 101,97 & 65,18 \\
\hline 3. & $\begin{array}{l}\text { PT Bekasi Fajar Industrial Estate } \\
\text { Tbk }\end{array}$ & 123,37 & 226,08 & 392,99 & 328,99 & 276,01 & 775,97 \\
\hline 4. & PT Bhuawanatala Indah Permai Tbk & 32,55 & 56,23 & 81,38 & 131,39 & 111,39 & 158,65 \\
\hline 5. & PT Bumi Citra Permai Tbk & 59,19 & 57,45 & 110,10 & 156,36 & 118,63 & 112,25 \\
\hline 6. & PT Bumi Serpong Damai Tbk & 97,60 & 46,78 & 265,87 & 301,63 & 237,35 & 336,19 \\
\hline 7. & PT Lippo Cikarang Tbk & 161,66 & 239,32 & 524,83 & 497,18 & 576,53 & 608,11 \\
\hline 8. & PT Lippo Karawaci Tbk & 495,39 & 517,17 & 691,39 & 545,57 & 513,68 & 453,16 \\
\hline 9. & PT Sentul City Tbk & 435,59 & 148,89 & 129,85 & 141,08 & 155,60 & 147,00 \\
\hline & Rata-rata rasio industri & 187,45 & 172,27 & 267,47 & 265,42 & 246,87 & 306,9 \\
\hline
\end{tabular}

Sumber : data diolah

Tabel 2

Hasil analisis rata-rata rasio industri debt to asset ratio pada perusahaan manufactur sub sektor properti tahun 2013 - 2018 ( dalam \% )

\begin{tabular}{llllllll}
\hline No & Perusahaan & 2013 & 2014 & 2015 & 2016 & 2017 & 2018 \\
\hline 1. & PT Agung Podomoro Land Tbk & 63,55 & 64,27 & 63,42 & 61,22 & 61,13 & 58,74 \\
\hline 2. & PT Alam Sutra Realty Tbk & 63,05 & 62,35 & 64,71 & 64,39 & 58,64 & 53,99 \\
\hline 3. & PT Bekasi Fajar Industrial Estate Tbk & 26,29 & 21,99 & 34,31 & 34,86 & 32,71 & 33,67 \\
\hline 4. & PT Bhuawanatala Indah Permai Tbk & 22,61 & 26,69 & 32,68 & 26,95 & 30,58 & 45,17 \\
\hline 5. & PT Bumi Citra Permai Tbk & 49,65 & 57,53 & 62,07 & 61,30 & 57,29 & 51,71 \\
\hline 6. & PT Bumi Serpong Damai Tbk & 40,57 & 34,34 & 38,66 & 36,46 & 36,46 & 41,87 \\
\hline 7. & PT Lippo Cikarang Tbk & 52,80 & 38,01 & 27,58 & 24,95 & 37,63 & 19,74 \\
\hline 8. & PT Lippo Karawaci Tbk & 54,70 & 53,27 & 54,23 & 51,81 & 47,40 & 48,86 \\
\hline 9. & PT Sentul City Tbk & 35,49 & 36,59 & 41,24 & 36,97 & 33,57 & 36,65 \\
\hline & Rata-rata rasio industri & 45,41 & 43,89 & 46,54 & 44,32 & 43,93 & 43,38 \\
\hline
\end{tabular}

Sumber : data diolah

Tabel 3

Hasil analisis rata-rata rasio industri debt to equity ratio pada perusahaan manufactur sub sektor properti tahun 2013 - 2018

\begin{tabular}{llllllll}
\hline No & Perusahaan & 2013 & 2014 & 2015 & 2016 & 2017 & 2018 \\
\hline 1. & PT Agung Podomoro Land Tbk & 1,73 & 1,79 & 1,73 & 1,58 & 1,47 & 1,42 \\
\hline 2. & PT Alam Sutra Realty Tbk & 1,70 & 0,62 & 1,68 & 1,97 & 1,41 & 1,17 \\
\hline 3. & PT Bekasi Fajar Industrial Estate Tbk & 0,26 & 0,21 & 0,52 & 0,53 & 0,49 & 0,50 \\
\hline 4. & PT Bhuawanatala Indah Permai Tbk & 0,29 & 0,27 & 0,40 & 0,37 & 0,44 & 0,82 \\
\hline 5. & PT Bumi Citra Permai Tbk & 0,99 & 1,35 & 1,63 & 1,58 & 1,34 & 1,07 \\
\hline 6. & PT Bumi Serpong Damai Tbk & 0,68 & 0,52 & 0,63 & 0,57 & 0,57 & 0,83 \\
\hline 7. & PT Lippo Cikarang Tbk & 1,11 & 0,61 & 0,38 & 0,33 & 0,60 & 0,24 \\
\hline 8. & PT Lippo Karawaci Tbk & 1,20 & 1,13 & 1,18 & 1,07 & 0,90 & 0,93 \\
\hline 9. & PT Sentul City Tbk & 0,55 & 0,57 & 0,70 & 0,58 & 0,50 & 0,53 \\
\hline & Rata-rata rasio industri & 0,95 & 0,79 & 0,98 & 0,93 & 0,85 & 0,83 \\
\hline
\end{tabular}

Sumber : data diolah 
Tabel.4.

Hasil Analisis rata-rata rasio industri return on equity pada perusahaan manufactur sub sektor properti tahun 2013 - 2018 ( dalam \% )

\begin{tabular}{llllllll}
\hline No & Perusahaan & 2013 & 2014 & 2015 & 2016 & 2017 & 2018 \\
\hline 1. & PT Agung Podomoro Land Tbk & $12,90 \mathrm{x}$ & $11,63 \mathrm{x}$ & $1,80 \mathrm{x}$ & $9,64^{*}$ & $15,96^{*}$ & $0,66 \mathrm{x}$ \\
\hline 2. & PT Alam Sutra Realty Tbk & $16,68 \mathrm{x}$ & $6,95 \mathrm{x}$ & $9,52^{*}$ & $7,73 \mathrm{x}$ & $16,16^{*}$ & $1,63 \mathrm{x}$ \\
\hline 3. & $\begin{array}{l}\text { PT Bekasi Fajar Industrial Estate } \\
\text { Tbk }\end{array}$ & $22,17^{*}$ & $10,71 \mathrm{x}$ & $6,97 \mathrm{x}$ & $9,92^{*}$ & $2,17 \mathrm{x}$ & $10,13^{*}$ \\
& & & & & & \\
\hline 4. & PT Bhuawanatala Indah Permai Tbk & $25,14^{*}$ & $3,18 \mathrm{x}$ & $11,60^{*}$ & $2,26 \mathrm{x}$ & $-2,56 \mathrm{x}$ & $-7,00 \mathrm{x}$ \\
\hline 5. & PT Bumi Citra Permai Tbk & $11,48 \mathrm{x}$ & $1,78 \mathrm{x}$ & $2,10 \mathrm{x}$ & $16,19^{*}$ & $17,00^{*}$ & $0,52 \mathrm{x}$ \\
\hline 6. & PT Bumi Serpong Damai Tbk & $21,66^{*}$ & $21,63^{*}$ & $10,64^{*}$ & $8,37 \mathrm{x}$ & $17,70^{*}$ & $26,61^{*}$ \\
\hline 7. & PT Lippo Cikarang Tbk & $32,47^{*}$ & $31,60^{*}$ & $22,63^{*}$ & $12,72^{*}$ & $4,77 \mathrm{x}$ & $32,21^{*}$ \\
\hline 8. & PT Lippo Karawaci Tbk & $11,23 \mathrm{x}$ & $17,77^{*}$ & $5,41 \mathrm{x}$ & $5,56 \mathrm{x}$ & $2,87 \mathrm{x}$ & $6,65 \mathrm{x}$ \\
\hline 9. & PT Sentul City Tbk & 8,80 & 0,66 & $0,94 \mathrm{x}$ & $7,85 \mathrm{x}$ & $4,71 \mathrm{x}$ & $3,47 \mathrm{x}$ \\
\hline & Rata-rata rasio industri & 18,06 & 11,77 & 7,96 & 8,92 & 8,75 & 8,32 \\
\hline
\end{tabular}

Sumber : data diolah

Tabel 5

Hasil Analisis rata-rata rasio industri Nett Profit Margin pada perusahaan manufaktur sub sector properti pada tahun 2013 - 2018 ( dalam \% )

\begin{tabular}{|c|c|c|c|c|c|c|c|}
\hline No & Perusahaan & 2013 & 2014 & 2015 & 2016 & 2017 & 2018 \\
\hline 1. & $\begin{array}{l}\text { PT Agung Podomoro Land } \\
\text { Tbk }\end{array}$ & 18,98 & 18,58 & 14,05 & 16,00 & 26,73 & 5,94 \\
\hline 2. & PT Alam Sutra Realty Tbk & 24,15 & 32,41 & 24,58 & 18,79 & 35,36 & 23,08 \\
\hline 3. & $\begin{array}{l}\text { PT Bekasi Fajar Industrial } \\
\text { Estate Tbk }\end{array}$ & 55,87 & 46,61 & 31,12 & 40,79 & 45,01 & 43,89 \\
\hline 4. & $\begin{array}{ll}\text { PT } & \text { Bhuawanatala } \\
\text { Permai Tbk } & \end{array}$ & 217,08 & 19,92 & 112,13 & 23,91 & $-28,53$ & $-60,64$ \\
\hline 5. & PT Bumi Citra Permai Tbk & 13,38 & 13,69 & 3,14 & 21,70 & 35,74 & 5,18 \\
\hline 6. & $\begin{array}{l}\text { PT Bumi Serpong Damai } \\
\text { Tbk }\end{array}$ & 50,61 & 71,73 & 37,87 & 31,24 & 49,93 & 37,72 \\
\hline 7. & PT Lippo Cikarang Tbk & 44,48 & 47,10 & 43,15 & 34,94 & 24,54 & 100,51 \\
\hline 8. & PT Lippo Karawaci Tbk & 23,89 & 26,90 & 11,49 & 11,65 & 7,75 & 13,85 \\
\hline 9. & PT Sentul City Tbk & 62,90 & 5,72 & 11,02 & 46,61 & 28,86 & 27,99 \\
\hline & Rata-rata rasio industri & 56,82 & 31,41 & 32,06 & 27,29 & 25,04 & 21,95 \\
\hline
\end{tabular}

Sumber : data diolah

\section{B. Pembahasan}

Pada tahun 2013 rata-rata industri curret rasio sebesar 187,45 dan perusahaan yang ada diatas rata-rata industri adalah PT.Lippo Karawaci Tbk , PT Sentul City Tbk. Tahun 2014 rata-rata industri current rasio sebesar 172,27 dan perusahaan yang ada diatas rata-rata industri adalah PT Lippo Karawaci,Tbk, PT Lippo Cikarang,Tbk, PT Bekasi Fajar Industrial, Tbk, PT Agung Podomoro Land Tbk.Tahun 2015 rata- rata industri current rasio sebesar 267,47 yang ada diatas rata- rata industri adalah PT Lippo Karawaci Tbk, PT Lippo Cikarang Tbk, PT Bekasi Fajar Industrial Tbk.Tahun 2016 rata-rata industri current rasio sebesar 265,42 yang ada diatas rata-rata industri adalah PT Lippo Karawaci Tbk, PT Lippo Cikarang Tbk, PT Bekasi Fajar Industrial Tbk, PT Bumi Serpong Damai Tbk, PT Agung Podomoro Land Tbk. Tahun 2017 rata-rata industri current rasio sebesar 246,87 yang ada diatas rata-rata industri adalah PT Lippo Cikarang Tbk, PT Lippo Karawaci Tbk, PT Bekasi Fajar Industrial Tbk. 
Tahun 2018 rata-rata industri current rasio sebesar 306,9 yang ada diatas rata-rata industri adalah PT Bekasi Fajar Industrial Tbk, PT Lippo Cikarang Tbk, PT Lippo Karawaci Tbk, PT Bumi Serpong Damai Tbk.

Pada tahun 2013 rata-rata industri debt to asset sebesar 45,41, perusahaan yang ada diatas rata rata adalah PT Agung Podomoro Land Tbk, PT Alam Sutera Realty Tbk, PT Lippo Karawaci Tbk, PT Lippo Cikarang Tbk, PT Bumi Serpong Damai Tbk.Tahun 2014 rata-rata industri debt to asset sebesar 43,89, perusahaan yang ada diatas rata-rata adalah PT Agung Podomoro Land Tbk, PT Alam Sutera Realty Tbk,PT Bumi Citra Permai Tbk, PT Lippo Karawaci.Tahun 2015 rata-rata industri debt to asset sebesar 46,54, perusahaan yang ada diatas rata-rata adalah PT Alam Sutera Realty Tbk, PT Agung Podomoro, PT Bumi Citra Permai Tbk, PT Lippo Karawaci. Tahun 2016 rata-rata industri debt to asset sebesar 44,32, perusahaan yang ada di atas ratarata industri adalah PT Alam Sutera Realty Tbk, PT Agung Podomoro Land Tbk, PT Bumi Citra Permai Tbk, PT Lippo Cikarang Tbk. Tahun 2017 rata-rata industri debt to asset sebesar 43,93, perusahaan yang ada diatas rata-rata industri adalah PT Agung Podomoro Land Tbk, PT Alam Sutera Realty Tbk, PT Bumi Citra Permai Tbk, PT Lippo Karawaci Tbk. Tahun 2018 rata-rata industri debt to asset sebesar 43,38, perusahaan yang ada diatas rata-rata industri adalah PT Agung Podomoro Land Tbk, PT Alam Sutera Realty Tbk, PT Bumi Serpong Damai Tbk, PT Lippo Karawaci Tbk, PT Bhuawanatala Indah Permai Tbk..

Pada tahun 2013 rata-rata industri debt to equity sebesar 0,95 , perusahaan yang ada diatas rata-rata industri adalah PT Agung Podomoro Land Tbk, PT Alam Sutera Realty Tbk, PT Lippo Cikarang Tbk, PT Lippo Karawaci Tbk.Tahun 2014 rata-rata industri debt to equity sebesar 0,79 , perusahaan yang ada diatas rata-rata industri adalah PT Agung Podomoro Land Tbk, PT Bumi Citra Permai Tbk, PT Lippo Karawaci Tbk.Tahun 2015 rata-rata industri debt to equity sebesar 0,98, perusahaan yang ada diatas rata-rata adalah PT Agung Podomoro Land Tbk, PT Alam Sutera Realty Tbk, PT Bumi Citra Permai Tbk, PT Lippo Krawaci Tbk.Tahun 2016 rata-rata industri debt to equity sebesar 0,93, perusahaan yang ada diatas rata-rata adalah PT Agung Podomoro Land Tbk, PT Alam Sutera Realty Tbk, PT Bumi Citra Permai Tbk, PT Lippo Karawaci Tbk.Tahun 2017 rata-rata industri debt to equity sebesar 0,85, perusahaan yang ada diatas rata- rata adalah PT Alam Sutera Realty Tbk, PT Agung Podomoro Land Tbk, PT Bumi Citra Permai Tbk, PT Lippo Karawaci Tbk. Tahun 2018 rata-rata industri debt to equity sebesar 0,83 , perusahaan yang ada diatas rata-rata industri adalah PT Agung Podomoro Land Tbk, PT Alam Sutera Tbk, PT Bumi Citra Permai Tbk, PT Lippo Karawaci Tbk.

Pada tahun 2013 rata-rata industri return on equity sebesar 18,06, perusahaan yang ada diatas rata-rata adalah PT Lippo Cikarang Tbk, PT Bumi Serpong Damai Tbk, PT Bhuawanatala Indah Permai Tbk,PT Bekasi Fajar Industrial Estate Tbk. Tahun 2014 rata-rata industri return on equity sebesar 11,77, perusahaan yang ada diatas rata-rata adalah PT Lippo Cikarang Tbk, PT Bumi Serpong Damai Tbk, PT Lippo Karawaci Tbk. Tahun 2015 rata-rata industri return on equity sebesar 7,96, perusahaan yang ada diatas rata-rata 
adalah PT Lippo Cikarang Tbk, PT Bhuawanatala Indah Permai Tbk, PT Bumi Serpong Damai Tbk. Tahun 2016 rata-rata industri return on equity sebesar 8,92, perusahaan yang ada diatas rata-rata adalah PT Bumi Citra Permai Tbk, PT Lippo Cikarang Tbk, PT Bekasi Fajar Industrial Estate Tbk, PT Agung Podomoro Land Tbk. Tahun 2017 rata-rata industri return on equity sebesar 8,75, perusahaan yang ada diatas rata-rata adalah PT Bumi Serpong Damai Tbk, PT Bumi Citra Permai Tbk, PT Alam Sutera Realty Tbk, PT Agung Podomoro Land Tbk. Tahun 2018 rata-rata industri return on equity sebesar 8,32 , perusahaan yang ada diatas rata-rata adalah PT Lippo Cikarang Tbk, PT Bumi Serpong Damai Tbk, PT Bekasi Fajar Industrial EstateTbk.

Tahun 2013 rata-rata industri net profit margin sebesar 58,82, perusahaan yang ada diatas rata-rata adalah PT Sentul City Tbk, PT Bhuawanatala Indah Permai Tbk. Tahun 2014 rata-rata industri net profit margin sebesar 31,41, perusahaan yang ada diatas rata-rata adalah PT Bumi Serpong Damai Tbk, PT Lippo Cikarang Tbk, PT Bekasi Fajar Industrial Estate Tbk, PT Alam Sutera Tbk.Tahun 2015 rata-rata industri net profit margin sebesar 32,06 , perusahaan yang ada diatas rata-rata adalah PT Bhuawanatala Indah Permai Tbk, PT Lippo Cikarang Tbk, PT Bumi Serpong Damai Tbk. Tahun 2016 rata-rata industri net profit margin sebesar 27,29, perusahaan yang ada diatas rata-rata adalah PT Sentul City Tbk, PT Bekasi Fajar Industrial Estate Tbk, PT Lippo Cikarang Tbk, PT Bumi Serpong Damai Tbk.Tahun 2017 rata-rata industri net profit margin sebesar 25,04, perusahaan yang ada diatas rata-rata adalah PT Bumi Serpong DamaiTbk, PT Bekasi Fajar Industrial Estate Tbk, PT Bumi Citra Tbk,
PT Alam Sutera Realty Tbk, PT Agung Podomoro Land Tbk, PT Lippo Cikarang Tbk.Tahun 2018 rata-rata industri net profit margin sebesar 21,95, perusahaan yang ada diatas rata-rata adalah PT Lippo Cikarang Tbk, PT Bekasi Fajar Industrial Estate Tbk, PT Serpong Damai Tbk, PT Sentul City Tbk, PT Alam Sutera Realty Tbk.

\section{IV.Kesimpulan}

Berdasarkan analisis yang telah dilakukan dan kesimpulan yang diperoleh, maka penulis akan memberi beberapa saran, yaitu bagi perusahaan untuk meningkatkan rasio liquiditasnya maka perusahaan harus mengoptimalkan modal kerja serta memelihara tingkat kredit yang menguntungkan. Perusahaan diharap mengelola modal yang berasal dari pinjaman secara efisien dan mengurangi pinjaman jangka panjang. Perusahaan harus mampu untuk menggunakan biaya secara efisien dan meningkatkan manajemen dalam pemanfaatan modal kerja.

Bagi peneliti selanjutnya peneliti menyarankan untuk lebih banyak lagi melakukan analisis keuangan dengan menggunakan rasio-rasio keuangan yang lain dengan menggunakan metode yang lebih baik dan komprehensif.

\section{Daftar Pustaka}

Alwi, Syafarudin , Alat-alat Analisis Dalam Pembelanjaan (Edisi Revisi). Yogyakarta: Andi Offset. 1989

Gito Sudarmo, Indriyo, dan Basri, Manajemen Keuangan . Edisi Ke Empat. Yogyakarta,BPFE,2002. 
Hanafi, M.Mamduh dan Halim, Abdul. Analisis Laporan Keuangan (Edisi Revisi). Yogyakarta: UPP AMP YKPN,2013

Hasnan, Suad, Manajemen Keuangan.Edisi Ke Empat Yogyakarta : BPFE, 1997.

Kasmir, Analisis Laporan keuangan , Jakarta, Rajawali Pers,2014.

Kloter, Philip. Manajemen Pemasaran di Indonesia. Jakarta : Salemba, 1997.

Martani, Dwi, Akutansi Keuangan Menengah Berbasis PSAK. Jakarta : Salemba Empat 2014.

Martin, Jhon D, Dasar Dasar Manajemen Keuangan, Jakarta : Raja Grafindo Persada,2014

Munawir, Analisa Laporan Keuangan. Edisi Ke Empat. Yogyakarta : LIBERTY,2010.

Nasution, Mutia, Raisa, Analisis Rasio Profitabilitas Sebagai Alat Untuk Menilai

Kinerja Keuangan Pada PT Jayawi Solusi Abadi Medan ( Skripsi ). Medan : Fakultas Ekonomi Dan Bisnis Islam, Universitas Islam Negeri Sumatera Utara (tidak diterbitkan),2018

Setyautama, Sam (Penerjemah). Memahami Laporan Keuangan. Jakarta : PT. Indeks,2004.

Astanto, Yoseph, Widhi, Perbandingan Rasio Keuangan Perusahaan Perdagangan
Eceran Yang Terdaftar di Bursa Efek Jakarta (Studi Empiris pada PT Alfa Retailindo Tbk., PT Hero Supermarket Tbk., PT Matahari Putra Prima Tbk., PT Ramayana Lestari Sentosa Tbk.,PT Rimo Catur Lestari Tbk.) ( Skripsi ). Fakultas Ekonomi, Universitas Sanata Dharma (tidak diterbitkan).2007 